THURSDAY, DECEMBER I, Igro.

HISTORY IN BRITISH PLACE-NAMES.

British Place-names in their Historical Setting. By Edmund McClure. Pp. 349. (London: Society for Promoting Christian Knowledge, 1910.) Price $5 s$.

THE loving labour of an average lifetime, "studies 1 in leisure hours extending over some thirty years and more," this work is an eloquent testimony to the value of the science of philology in the elucidation of historical nuaterials. It is both a history and a valuable guide to the philology of British placenames "as they occur chronologically in authentic historical documents from 54 B.C. until A.D. II $54 . "$ In his last paragraph, the author explains why he draws a line at Stephen's death.

"The consideration of later records containing placenames is not worth pursuing, as the forms therein presented vary but little from those now in use, and the new terms introduced by the continental monastic orders, such as Beaulieu, Rievaulx, Jervaulx, \&c., explain themselves" (p. 304).

The phrase "not worth pursuing" surely needs some qualification, and the explanation offered implies that the author is satisfied that later documents contain no material additions to his list of historical place-names.

Very appropriately, "a short summary of the modern methods employed in linguistic research" is given at the beginning, to "illustrate the statement in the text and show the truly scientific character of comparative philology" (p. 13). The text is mainly a history of Britain with the place-names worked in, the latter elaborately discussed in "notes" and footnotes. The thoroughness, as well as the duration, of the author's studies are well attested by the numerous catenæ of name-forms. The best authorities on place-names are cited. Yet the author exhibits throughout a commendable critical independence, as well as personal detachment from pet theories, or theories one would have liked to press from personal conviction. When he discusses rival theories, as in the case of the Picts and their language, he gives a clear idea of the situation.

Considering the great advance made in philology and historical criticism in the last thirty years, such a work as this is must have been periodically revised to a large extent. Specialists in certain lines of inquiry would have expected further revision of some of the information given. The author betrays a suspicion of the genuineness of Gildas's "Destruction of Britain," the spuriousness of which has recently been demonstrated by $\mathrm{Mr}$. Wade Evans and others. In the discussion of sites of battles fought by Arthur, no reference is made to Mr. Anscombe's clever elucidation of the place-names. Sir John Rhys is, of course, the most frequent witness in the author's court, but while the latest edition of the classic "Celtic Britain" has been consulted, no reference is made to that eminent scholar's contributions to the British Academy and the Cymmrodorion Society within the last seven years or so. The author's remark that "the nucleus of the work has already appeared in a serial" sufficiently accounts for the belatedness, in these expeditious days, of some sections of the work. Finality in a work of such a comprehensive design is out of the question, and such omissions as those noted above affect only very slightly the unquestioned usefulness of the work as it is.

The author seems to have a very firm grip of the Scandinavian element in British place-names, a subject which is coming more and more to the fore. In his discussion of the place-names of Shetland and the Orkneys, which are "almost exclusively Scandinavian" ( that he is unwilling to go as far as his evidence goes, and one's attention is arrested by a doubtful deduction.

"As Orkn in Norse means a seal, Orkn-eyjar woula seem a natural designation for these islands, but the term $O r c$ in Orcades goes back to classical times, long before a Northman had put his foot upon them, and its meaning must be sought in the language of the earliest inhabitants" (p. 225).

The facts cited favour a theory of a very early occupation of the Orkneys by Scandinavians, and other evidence may be adduced to the same effect, but all that evidence must be laid aside, because the author is satisfied with some late date for such occupation, and with "classical" spellings of place-names in Britain. On general grounds, alleged dates of the beginnings of great racial migrations are open to a reasonable suspicion, and "classical" references to places in Britain cannot be accepted as final as against overwhelming local evidence.

The perusal of this scholarly, yet readable, book, in which history and philology are made to eludicate each other, opens up a vast field of inquiry, in which archæology, anthropology, and astronomy should also be requisitioned. We have given us an estimate of the value of documentary place-names. A companion volume on the documentary value of place-names in current use, or unrecorded in the documents examined by the author, would be very acceptable. The book is a marvel of compression, and an index of forty-five pages makes it a most welcome work of reference.

JOHN GRIFFITH.

\section{THE CHEMISTRY OF THE ALKALOIDS.}

Die Alkaloide. By Prof. E. Winterstein and Dr. G. Trier. Pp. vii +340 . (Berlin: Gebrüder Borntraeger, I910.) Price II marks.

SINCE Derosne and Sertürner isolated morphinc, $S$ the crystalline principle of opium, about a century ago, the separation of the natural bases from plants has always taken a prominent place in chemical research. To-day the number of these substances exceeds two hundred, and the list is probably far from complete. The process of their isolation is usually accompanied by a study of their therapeutic value and by the more difficult and fascinating task of discovering their structure. Of the pioneers in this branch of chemistry, A. W. Hofmann stands in the forefront. Following the earlier discoveries of Gerhardt on the relation of the pyridine bases to the alkaloids, he was able by the aid of new and ingenious methods of dis-

NO. 2 I 44 , VOL. 85 ] 